\title{
Does The Glass Ceiling Exist? A Longitudinal Study Of Women's Progress On French Corporate Boards
}

Rey Dang, La Rochelle Business School, France

Duc Khuong Nguyen, IPAG Business School, France Linh-Chi Vo, EM Normandie, France

\begin{abstract}
In this article, we conduct a longitudinal study of women's progress on French corporate boards of directors. We particularly focus on the extent to which women directors have circumvented the glass ceiling. Using a sample of SBF 120 companies over a 10-year period from 2000 to 2009, our results provide evidence of a significant increase in the number of women on French corporate boards. However, the corporate glass ceiling hypothesis is consistently rejected whatever the considered measure of female directors; i.e., the number of board seats held by women, the number of firms with a critical mass of female directors, and the number of directorships held by each women director.
\end{abstract}

Keywords: Boards of Directors; Gender; Diversity; Corporate Governance

\section{INTRODUCTION}

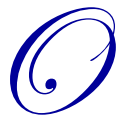

ver the period 2000-2009, the average participation rate of women in the labor market increased from 60 to 64 percent across the European Union's 27 Members States. More specifically, in France, it went up from 60.3 to 64.9 percent. ${ }^{1}$ However, despite this notable progress, women remain under-represented in senior or executive positions (ILO, 2009). ${ }^{2}$ This lack of female representation on corporate boards of directors, which is commonly referred to as glass ceiling in practice and past academic studies, seems to be a global phenomenon because women on corporate boards (WOCB) represents less than $15 \%$ of board members in the United States, United Kingdom, Canada, Australia, and many European countries (Dang \& Vo, 2012). ${ }^{3}$ Morrison et al. (1987) describe the glass ceiling as a "transparent barrier that keeps women from rising above a certain level in corporations. It applies to women as a group who kept from advancing higher because they are women." In general, the metaphor of "glass ceiling" implies the existence of a visible or an invisible barrier that prevents the vertically mobility of women. Below this barrier, women are able to get promoted, and beyond this barrier, they are unable. Studies including, among others, Daily et al. (1999), and Arfken et al. (2004) have put forward this argument to explain the under-representation of women in the boardrooms.

Removing the glass ceiling may make good business sense for two main reasons. First and foremost, the glass ceiling can lead to disillusionment and higher turnover among talented women who may have acquired valuable firm-specific knowledge and whose abilities are valuable to the organization (Powell, 1999). Second, perpetuating this established fact may signal a bad business culture to corporate stakeholders as it is related to how an organization treats and promotes its employees overall. According to Pfeffer (1981), if functionally irrelevant factors are used to exclude women from top management positions, both women and men in lower management levels could jeopardize their desire to remain with the organization.

\footnotetext{
${ }^{1}$ See European Labor Force Survey database (Eurostat); the report is accessible at: http://epp.eurostat.ec.europa.eu/portal/page/portal/microdata/lfs.

${ }^{2}$ International Labor Organization (ILO), March 2009, Global Employment Trends for Women.

${ }^{3}$ Excluding the Scandinavian countries.
} 
Over recent decades, considerable attention has been given to the question of whether women are able to shatter the glass ceiling and to make inroads in the boardroom. Past studies have examined this issue in a wide range of countries using various methodologies and measures of women's representation on corporate boards (e.g., Dang \& Vo, 2012; Terjesen et al., 2009; and references therein). Empirical investigations conducted in countries such as the U.S., UK, Canada, and Australia, among others, show that women are in minority on corporate boards, suggesting that they are tokens and that the glass ceiling still exists until now. Regarding France, we document that if women account for $52.4 \%$ of the labor force (INSEE, 2012), they only hold, among the 40 largest companies of the French stock market (CAC40 companies), $8.5 \%$ of board seats. ${ }^{4}$ It is also important to note that only a few studies have devoted to the investigation of the WOCB issue in the French context, while this country naturally differs from the other countries in terms of institutional and legal backgrounds as well as firms' specific characteristic. To the best of our knowledge, only three studies have examined this phenomenon through the business case for board gender (Belghiti-Mahut \& Lafont, 2010) and the organizational predictors of WOCB lens (Moulin \& Point, 2012; Nekhili \& Gatfaoui, 2012).

In this article, we contribute to the related literature by examining women's progress on French corporate boards and the extent to which women have shattered the glass ceiling. Specifically, we conduct a longitudinal study over the 10-year period from 2000 to 2009 for a sample of SBF 120 companies, to test the proposition that increased women's representation on boards is likely to provide strong evidence of women having circumvented the glass ceiling. Our approach is based on the theoretical perspective discussed in Terjesen et al. (2009), which states that the influence of female directors can be analyzed at the board level and its composition. By investigating the glass ceiling phenomenon over a relatively long period (ten years) instead of a cross-sectional study at a single point in time, our analysis allows us to examine the dynamic changes in gender diversity practices within the French context. The remainder of this article is organized as following. Section 2 briefly reviews the relevant literature devoted to the progression of WOCB. Section 3 presents the methodology used, sources of information and sample data. Section 4 reports and discusses the empirical results. Section 5 offers some concluding remarks.

\section{WOMEN'S REPRESENTATION ON CORPORATE BOARDS}

This section reviews the scientific literature published in leading financial, management, and strategic journals from 1990 through 2013 devoted to women's representation on corporate boards. ${ }^{5}$ We set arbitrary the year 1990 as the starting point for our analysis. However, to our best knowledge, no studies before 1990 have ever examined this issue (theoretically and empirically). In order to identify relevant articles, we perform queries on bibliographic databases (such as EBSCO Business Source Premier and ScienceDirect) choosing all academic articles that the terms "women" and "board of directors" (or "board") in the title, the abstract, or the keywords.

Table 1 summarizes the empirical studies we retrieve within the financial, management, and strategic literature. Specifically, we present their main results on the progression of female director representation in corporate boards.

Table 1: Women's Representation on Corporate Boards: Empirical Evidence

\begin{tabular}{cll}
\hline \multicolumn{1}{c}{ Article } & $\begin{array}{c}\text { Data (Country \& } \\
\text { Study Period) }\end{array}$ & \multicolumn{1}{c}{ Main Results } \\
\hline $\begin{array}{l}\text { Conyon \& Mallin } \\
(1997)\end{array}$ & $\begin{array}{l}\text { UK }\left(\text { FTSE } 350^{(\mathbf{a})}\right), \\
1995\end{array}$ & $\begin{array}{l}\text { 1995, women held 2.49\% of the FTSE board seats. This figure is slightly higher } \\
\text { Overall, 20.86\% of the FTSE 350 companies had at least one woman on the } \\
\text { corporate board. Among the FTSE 100 companies, this ratio stood at 40.00\% and } \\
13.20 \% \text { for the Mid-250 companies. }\end{array}$ \\
\hline Burke (1999) & Canada, 1996 & $\begin{array}{l}\text { In 1996, the average top 1000 Canadian board of directors had } 8.5 \text { members, of } \\
\text { whom 8.1 men and 0.4 women. }\end{array}$ \\
\hline
\end{tabular}

\footnotetext{
${ }^{4}$ INSEE stands for Institut National de la Statistique et des Études Économiques, which is the French National Institute for Statistics and Economics Studies. INSEE, 2012, Femmes et hommes - Regards sur la parité, Paris: Insee Références.

${ }^{5}$ In this case, we do not take into consideration the results published by private organizations (such as Catalyst) or public ones (e.g., European Commission).
} 
Table 1 cont.

Daily et al. (1999) USA (Fortune $500^{(\mathbf{b})}$ ), $1987 \& 1996$

In 1987 , on average, $42.6 \%$ of the Fortunes companies had women on their corporate board. In 1996, this ratio stood at $81.2 \%$.

Moreover, the average board in 1996 had 1.2 women compared with 0.54 women in 1987. The difference is statistically significant at the $1 \%$ level.

Women held $5.81 \%$ of the FTSE 100 board seats in 2000 and $6.29 \%$ in 1999.

In $1999,64.0 \%$ of the FTSE 100 companies had at least one female director on

Singh et al. (2001) UK (FTSE $100^{(\mathbf{c})}$ ), $1999 \& 2000$ corporate board, but this went down to $58.0 \%$ in 2000. Specifically, $13 \%$ of firms had at least 2 WOCB, compared with $12 \%$ in 1999.

Note that only one woman held three directorships among FTSE companies, whilst 10 female directors held two FTSE directorships.

USA (Publicly traded In 2002, on average, women held 5.8\% of board seats of Tennessee companies companies in compared with $5.4 \%$ in 1996.

Arfken et al. (2004) $\quad$ companies in 1996 \&

In their original study (Arfken et al., 1998), only $25 \%$ of companies, in 1996, had at least one woman on corporate board. In 2002, this figure stood at $38 \%$.

Women held $7.2 \%$ of directorships in 2002, up from $6.4 \%$ in 2001.

The number of companies with female directors among the UK's top 100 firms had gone from $64 \%$ in 1999 to $57 \%$ in 2001, increase to $61 \%$ in 2002.

Singh \& UK (FTSE $\left.100^{(\mathbf{b})}\right)$, Vinnicombe (2004) $2001 \& 2002$ None of the FTSE 100 companies had more than three female directors. 6 firms had $20-27 \%$ WOCB, compared with only one in 2000. Finally, 28 FTSE 100 companies had 10-19\% WOCB, and 27 firms had 5-9\% female representation on their boards in 2002.

$\begin{array}{ll}\text { Carter et al. (2003) } & \text { USA (Fortune } \\ \left.1000^{(d)}\right), 1997\end{array}$

Women held $9.6 \%$ of Fortune 1000 board seats in 1997. The average board size is nearly 11 , of whom, 1.1 are women. $46.9 \%$ of these companies had at least one woman on corporate boards, while $24.8 \%$ did not have any WOCB.

Women held $12.2 \%$ of Fortune 500 and Service 500 board seats in 1999 and $7.4 \%$ in 1990 (with $8.2 \%$ in 1994). The average number of WOCB increased from 0.74 in 1990 to 1.39 in 1999.

$\begin{array}{cl}\text { Farrell \& Hersch } & \text { USA (Fortune } 500^{(\mathbf{b})} \\ (2005) & \left.\text { Service } 500^{(\mathbf{e})}\right),\end{array}$
1990-1999
In 1990, in average, the percentage of firms without WOCB in 1990 is $47.0 \%$. This figure, by 1999 , fells significantly to $12.6 \%$ (1994: $27.6 \%$ ).

In $1990,36.4 \%$ of the firms had only one woman on corporate board, $13.6 \%$ had two women on the board, and $2.9 \%$ had at least $3 \mathrm{WOCB}$, compared with respectively $45.8 \%, 33.6 \%$, and $8.0 \%$ in 1999 .

Finally, despite a decrease in board size (from 12.1 in 1990 to 11.3 in 1999), the representation of women increased significantly.

\begin{tabular}{|c|c|c|}
\hline $\begin{array}{l}\text { Brammer et al. } \\
(2007)\end{array}$ & $\begin{array}{l}\text { UK (FTSE All } \\
\left.\text { Share }^{(\mathrm{f})}\right), 2002\end{array}$ & $\begin{array}{l}\text { In } 2002,37 \% \text { of the firms listed on the LSE had at least one female director. } \\
\text { The average board size consists of } 8.4 \text { men, of whom, } 0.5 \text { is woman. }\end{array}$ \\
\hline $\begin{array}{l}\text { Campbell \& } \\
\text { Mínguez-Vera } \\
\text { (2008) }\end{array}$ & $\begin{array}{l}\text { Spain (Non-financial } \\
\text { firms listed Bolsa de } \\
\left.\text { Madrid }^{(\mathbf{g})}\right), 1995-2000\end{array}$ & $\begin{array}{l}\text { Over the period, women held } 3.3 \% \text { of board seats of largest Spanish companies. Only } \\
23.7 \% \text { of Spanish-quoted firms have one or more WOCB. }\end{array}$ \\
\hline $\begin{array}{l}\text { Adams \& Ferreira } \\
\text { (2009) }\end{array}$ & $\begin{array}{l}\text { USA (S\&P 500, S\&P } \\
\text { MidCaps, and S\&P } \\
\text { Small Cap), 1996- } \\
2003\end{array}$ & $\begin{array}{l}\text { Over the period, women held } 10.4 \% \text { of board seats among companies in the S\&P } \\
\text { indexes. This ratio has increased by } 25 \% \text { over time, with } 8.1 \% \text { in } 1996 \text {. } \\
\text { The proportion of S\&P companies having only one woman on their boards remained } \\
\text { unchanged throughout the analysis period at } 40 \% \text {. }\end{array}$ \\
\hline Carter et al. (2010) & $\begin{array}{l}\text { USA (S\&P 500), } \\
1998-2002\end{array}$ & $\begin{array}{l}\text { The average number of female directors over the period } 1998-2002 \text { is } 1.30 \text {, with an } \\
\text { average board size of } 11.2 \text { directors. }\end{array}$ \\
\hline $\begin{array}{l}\text { Simpson et al. } \\
\quad(2010)\end{array}$ & $\begin{array}{l}\text { USA (S\&P 1500), } \\
2003-2007\end{array}$ & $\begin{array}{l}\text { On average, women held } 14.5 \% \text { board seats of S\&P } 500 \text { companies }(2003-2007) \text {. } \\
\text { The authors also find that the percentage of board seats held by women has increased } \\
\text { from } 10.4 \% \text { (in 1998) to } 14.8 \% \text { (in 2007). } \\
\text { About } 47 \% \text { of the S\&P } 500 \text { companies had at least one woman on corporate board, in } \\
2007 \text {. But only nearly } 27 \% \text { for the S\&P MidCaps and S\&P } 600 \text { SmallCap companies. } \\
\text { The difference in the means between each group is statically significant. }\end{array}$ \\
\hline $\begin{array}{l}\text { Nekhili \& Gatfaoui } \\
\text { (2013) }\end{array}$ & $\begin{array}{l}\text { France (SBF 120), } \\
2000-2004\end{array}$ & $\begin{array}{l}\text { Women held } 7.20 \% \text { of SBF } 120 \text { board seats in } 2004 \text { and } 6.27 \% \text { in } 2000 \text {. In } 2004 \text {, the } \\
\text { number of SBF } 120 \text { companies with no WOCB represents more than } 50 \% \text {. About } \\
30 \% \text { of firms had only one woman on their boards, while } 20 \% \text { had two women on } \\
\text { more on the board of directors. }\end{array}$ \\
\hline
\end{tabular}

(a) The FTSE 350 index is a market capitalization weighted market index that gathers the largest 350 companies by capitalization listed on the London Stock Exchange (LSE). ${ }^{\text {(b) }}$ The Fortune 500 is an annual list compiled and published by Fortune magazine that ranks the top 500 U.S. companies ranked by revenue. ${ }^{(\mathbf{c})}$ The FTSE 100 companies comprises the 100 largest companies on the LSE. ${ }^{(\mathbf{d})}$ The magazine Fortune compiles in a similar manner the 1000 largest U.S. companies in terms of revenues. ${ }^{(e)}$ In 1990, the magazine Fortune had two separate lists: The Fortune 500 tracked the largest U.S. industrial companies and the Service 500 tracked the largest U.S. non-industrial companies (Farrell \& Hersch, 2005).

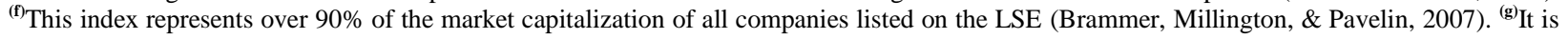
the largest and most international of Spain stock exchanges. 
As we can see in Table 1, while previous studies have generally documented the progression of women's representation in corporate boards for various countries, the number of seats held by women may not be sufficient enough to have a significant influence in the board activities and firm performance. This under-representation suggests that women in management and in the boardrooms are almost always in the token position (Kanter, 1977). Following the critical mass theory (Granovetter, 1978; Kanter, 1977), women directors influence board decisions only when their representation reaches a certain threshold, or a "critical mass." Konrad et al. (2008) suggest that the critical mass of women is reached when boards of directors have at "least three women." In this case, women's voices and ideas are taken into account in the boardroom. In this study, we also examine these theoretical arguments by using a dataset from France over the last decade.

\section{DATA AND METHODOLOGY}

We gather the information on corporate gender diversity from five sources of information: company's annual reports, Who's Who, Factiva, Diane, and the Internet. All annual reports were downloaded from companies' websites. In the biography section, there is information regarding directors' names, age (or birth date), education, function and position, and year of appointment. We crosscheck or complete all collected information by using Who's Who which is a biographical dictionary that lists the people who matter in France, Factiva which generally publishes director appointments, and the Diane database (Bureau van Dijk). The Internet provides us with information not covered by the other sources. Based on these sources of information, we reconstruct the composition of director boards as of 31 December 2000, 2004, and 2009.

Our sample data consist of the companies listed in the SBF 120 stock market index of Euronext Paris at the end of fiscal years 2000, 2004, and 2009. This market index gathers the 120 largest companies by market capitalization and by trading volume on NYSE Euronext Paris. The final sample includes 104, 112, and 120 in 2000, 2004, and 2009, respectively. We could not include all the 120 companies in 2000 and 2004 due to the unavailability of some annual reports. The choice of this index is explained by our ambition to conduct an investigation at a scale similar to that of existing Anglo-Saxon studies, which all use samples of large firms. For instance, Daily et al. (1999) analyze the US firms belonging to the "Fortune 500" corporations, while Sealy et al. (2009) study the British companies included in the FTSE 100 Index. It is worth mentioning that our study stands prior the vote of the law Copé-Zimmermann in 2011, which requires the presence of at least $40 \%$ of female directors in corporate boards. Thus, our analysis enables us to examine the progression of women on corporate boards in an unregulated context of gender diversity.

Following Hillman et al. (2002), we investigate the glass ceiling hypothesis for French corporate boards by performing the t-test and the Wilcoxon test.

\section{RESULTS}

Similar to Daily et al. (1999), and Simpson et al. (2010), we analyze women's progress in corporations by using two common measures: (i) the proportion of firms having at least one woman in the boardroom; and (ii) the proportion of board seats held by women.

Table 2 shows that, in 2009, 68.3\% of the companies listed on the SBF 120 index have at least one woman on their boards, compared to $40 \%$ and $49 \%$ in 2000 and 2004, respectively. Over one decade, this proportion increased about $69 \%$. The difference in the means between 2009 and 2000 is statistically significant at the $1 \%$ level, suggesting that more SBF 120 companies have appointed at least one female director in their corporate boards. The mean difference between 2004 and 2000 is, however, not significant.

Table 2: Proportion of SBF 120 Companies with One or More Women Directors

\begin{tabular}{lccccc}
\hline \multicolumn{1}{c}{ Year } & N & Mean & Standard deviation & T-test & Wilcoxon \\
\hline 2000 & 103 & 40.38 & 49.30 & & 1.49 \\
2004 & 112 & 50.43 & 50.22 & $4.33^{* * * *}$ & 1.49 \\
2009 & 120 & 68.33 & 46.71 & $2.83^{* * * *}$ & $4.19^{* * * *}$ \\
Period 2004-2009 & & & $2.79^{* * * *}$ \\
\hline
\end{tabular}

Data are derived from the own calculation of the authors. The t-test and the Wilcoxon rank-sum test in each year examine whether the average proportion of board seats held by women among SBF 120 companies in 2004 and 2009 is significantly different from that of the year $2000 .\left(^{* * *}\right),\left({ }^{* *}\right)$, and $\left(^{*}\right)$ indicates significance at the $1 \%, 5 \%$, and $10 \%$ levels. 
Table 3 shows that women held $9.3 \%$ of the SBF 120 board seats in 2009, compared to $6.1 \%$ and $7.0 \%$ in 2000 and 2004, respectively. Thus, the proportion of board seats held by women to total board seats increased 53\% over the period 2000-2009. This increase is statistically significant at the $1 \%$ level for the year 2009 against the year 2000, but insignificant for the year 2004 against the year 2000. Again, the findings point to the higher representation of female directors in corporate boards.

Table 3: Proportion of Board Seats Held by Women Among SBF 120 Companies

\begin{tabular}{lccccc}
\hline \multicolumn{1}{c}{ Year } & $\mathbf{N}$ & Mean & Standard deviation & T-test & Wilcoxon \\
\hline 2000 & 103 & 6.11 & 10.01 & & 0.82 \\
2004 & 112 & 7.18 & 9.19 & $2.56^{* * * *}$ & 1.28 \\
2009 & 120 & 9.37 & 8.92 & $1.86^{* * *}$ & $3.59^{* * * *}$ \\
Period 2004-2009 & & & $2.36^{* * * *}$ \\
\hline
\end{tabular}

Data are derived from the own calculation of the authors. The sample unit is the board seat for a company, not a particular director. If a director serves on two or more boards, that individual director will be counted more than once in the computed numbers in this table. The t-test and the Wilcoxon rank-sum test in each year examine whether the average proportion of board seats held by women among SBF 120 companies in 2004 and 2009 is significantly different from that of the year $2000 .\left({ }^{* * *}\right),\left({ }^{* *}\right)$, and $\left(^{*}\right)$ indicates significance at the $1 \%, 5 \%$, and $10 \%$ levels.

The analysis based on Tables 2 and 3 so far provides only surface information. It may fail to support any evidence or provide a clear-cut conclusion that women have shattered the glass ceiling. Therefore, we propose to go further into our analysis of women's progress on French corporate boards by analyzing three additional dimensions, as suggested by Sealy et al. (2009): (i) the number of board seats held by women; (ii) the number of firms with a critical mass of female directors on boards; and (iii) the number of directorships held by each female director.

A close look at the figures in Table 4 reveals that 134 board seats are held by women in 2009 for the whole sample, against only 68 in 2000 and 82 in 2004 . The ratio of board seats held by women to total board seats is $9.41 \%$, compared with nearly $6 \%$ in 2000 . On average, one female director is on the board of each SBF 120 company for the year 2009, compared with 0.65 in 2000. Finally, in 2009, the number of female directors on French corporate boards rose from 42 in 2000 to 82 in 2009 . The results from the t-test applied to the differences in number of seats held by women and percentage change across years indicate that the increase in level and percentage between 2009 and 2000 is significant at the $1 \%$ level.

Table 4: Evolution of the Number of Female Directors

\begin{tabular}{|c|c|c|c|}
\hline Year & 2000 & 2004 & 2009 \\
\hline Total number of seats & 1,220 & 1,281 & 1,424 \\
\hline Seats held by women & 68 & 82 & $134^{* * * *}$ \\
\hline Percentage & 5.57 & 6.40 & $9.41^{* * *}$ \\
\hline Board size & 11.87 & 11.24 & 11.87 \\
\hline Average number of female directors & 0.65 & 0.74 & 1.12 \\
\hline
\end{tabular}

Data are derived from the own calculation of the authors. The sample unit is the board seat for a company, not a particular director. If a director serves on two or more boards, that individual director will be counted more than once in the computed numbers in this table. The t-test is used to measure the evolution of the number of female directors with 2000 as a pivotal year. $\left({ }^{* * *}\right)$ indicates significance at the $1 \%$ level.

We now turn to the critical mass of female directors on French corporate boards between 2000 and 2009. Table 5 shows that in 2009, nearly one third of SBF 120 companies have no women on boards. The proportion of SBF 120 companies having no female directors on boards decreased significantly at conventional levels over the period. The majority of the firms of our sample have only one woman on board (42.5\% in 2009, compared with nearly $25 \%$ in 2000). The difference in the means is statistically significant. However, the number of firms with at least two women directors rises over the sample period: $25.8 \%$ in 2009 , compared with $16.4 \%$ in 2000 . This increase is only significant at the $10 \%$ level. 
Table 5: Number of Firms with a Critical Mass of Female Directors

\begin{tabular}{lcccccc}
\hline \multirow{2}{*}{ Number of Female Directors } & \multicolumn{2}{c}{$\mathbf{2 0 0 0}$} & \multicolumn{2}{c}{$\mathbf{2 0 0 4}$} & \multicolumn{2}{c}{$\mathbf{2 0 0 9}$} \\
\cline { 2 - 7 } & Number & As \% & Number & As \% & Number & As \% \\
\hline No female director & 62 & 59.62 & 57 & $50.89^{* * *}$ & 39 & $31.67^{* * * * *}$ \\
One female director & 25 & 24.04 & 40 & $35.71^{*}$ & 51 & $42.50^{* * * *}$ \\
Two female directors & 9 & 8.65 & 9 & 8.04 & 17 & 14.17 \\
More than two female directors & 8 & 7.69 & 6 & 5.36 & 14 & 11.67 \\
\hline
\end{tabular}

Data are derived from the own calculation of the authors. The sample unit is the board seat for a company, not a particular director. If a director serves on two or more boards, that individual director will be counted more than once in the computed numbers in this table. The t-test is used to measure the critical mass of female directors with 2000 as a pivotal year. $\left({ }^{* * *}\right),\left({ }^{* *}\right)$, and $\left({ }^{*}\right)$ indicate significance at the $1 \%, 5 \%$, and $10 \%$ levels, respectively.

We now look at the number of directorships held by female directors over the period 2000-2009. Specifically, we restrict our analysis to the directorships of the SBF 120 companies and focus on the "elite social networks," as suggested by D'Aveni and Kesner (1993). Indeed, this core elite group represents the "inner circles" among director elite. These directors differ significantly from the larger categories of directors with respect to their social characteristics and their institutional affiliation (Allen, 1978; Useem \& Karabel, 1986). This is particularly prevalent in the French context as (Bourdieu, 1996) emphasizes. Indeed, they are graduated from an elite institution (Grande École) and have spent several years on the labor market within the civil services (Grands Corps d'État) (Nguyen, 2012).

The analysis of Table 6 shows that in 2009, among the 115 female directors, 100 (or $87 \%$ ) hold a single SBF 120 companies directorship; more than $10 \%$ (or 15 women) had two or more directorships. We also note that these figures remain relatively stable over the study period.

Table 6: Breakdown of the Number of Directorships Held by Women in SBF 120 Companies

\begin{tabular}{lcccccc}
\hline & $\mathbf{2 0 0 0}$ & & $\mathbf{2 0 0 4}$ & \multicolumn{2}{c}{$\mathbf{2 0 0 9}$} \\
\cline { 2 - 6 } & Number & As \% & Number & As \% & Number & As \% \\
\hline One directorship & 44 & 83.02 & 55 & 87.30 & 100 & 86.96 \\
Two directorships & 6 & 11.32 & 4 & 6.35 & 13 & 11.30 \\
More than two directorships & 3 & 5.66 & 4 & 6.35 & 2 & 1.74 \\
\hline
\end{tabular}

Data are derived from the own calculation of the authors. The t-test is used to measure the breakdown of the number of of directorships held by women with 2000 as a pivotal year.

\section{CONCLUDING REMARKS}

The primary objective of this study is to examine women's progress on French corporate boards over the period 2000-2009. Our findings show some intriguing facts regarding the evolution of corporate gender diversity in the French boardrooms, which precedes the promulgation of the law requiring a minimum quota of female directors. First, we find a significant increase of women on French corporate boards during the period 2000-2009, suggesting that women have been able to shatter the glass ceiling. We also notice that the number of board seats held by at least a female director as well as the proportion of female director seats to total board seats have significantly increased over the period 2004-2009. Before this period, the progress of women in the boardroom is relatively marginal, as indicated by the insignificance of the differences in means. However, almost one third of the companies of the SBF 120 index do not have any female directors on their boards in 2009, against nearly $60 \%$ in $2000.41 .3 \%$ of firms included in the SBF 80 have no women on their boards, compared to only $12.5 \%$ for the CAC 40 companies. ${ }^{6}$ When we examine the number of directorships held by women, we find that the vast majority of SBF 120 companies had either one single female director or no female directors on their boards. Similarly, the proportion of firms having more than two or three female directors still remains low. Taken together, our results support the continuation of tokenism and the glass ceiling among French firms.

\footnotetext{
${ }^{6}$ The SBF 120 index gathers the 120 largest market capitalizations on Euronext Paris. It is made up of the CAC 40 and the SBF 80 . The latter includes the SBF 120 securities that are not included in the CAC 40.
} 


\section{AUTHOR INFORMATION}

Dr. Rey Dang is Assistant Professor of Finance at La Rochelle Business School \& LEO (Laboratoire d'Economie d'Orléans), University of Orléans, France. His main research areas cover corporate governance, board gender diversity, and firm performance. E-mail: dangr@esc-larochelle.fr

Dr. Duc Khuong Nguyen is Professor of Finance and Deputy Director for Research at IPAG Business School, France. His principal research areas concern corporate governance, emerging markets finance, energy finance, volatility modeling, and risk management in international capital markets. E-mail: duc.nguyen@ipag.fr (Corresponding author)

Dr. Linh Chi Vo is Associate Professor at Ecole de Management de Normandie and Associate Researcher at Ecole Centrale Paris. Her research areas include knowledge management, innovation, board gender diversity, and the philosophy of pragmatism. E-mail: 1vo@em-normandie.fr

\section{REFERENCES}

1. Adams, R. B., \& Ferreira, D. (2009). Women in the boardroom and their impact on governance and performance. Journal of Financial Economics, 94(2), 291-309.

2. Allen, M. P. (1978). Continuity and change within the core corporate elite. Sociological Quarterly, 19(4), 510-521.

3. Arfken, D. E., Bellar, S. L., \& Helms, M. M. (1998). The ultimate glass ceiling: Women on corporate boards. A Leadership Journal: Women in Leadership - Sharing the Vision, 3(1), 95-105.

4. $\quad$ Arfken, D. E., Bellar, S. L., \& Helms, M. M. (2004). The ultimate glass ceiling revisited: The presence of women on corporate boards. Journal of Business Ethics, 50(2), 177-186.

5. Ashforth, B. E., \& Mael, F. (1989). Social identity theory and the organization. Academy of Management Review, 14(1), 20-39.

6. Belghiti-Mahut, S., \& Lafont, A.-L. (2010). Lien entre présence des femmes dans le top management et performance financière des entreprises en France. Gestion 2000, 5, 131-146.

7. Bilimoria, D., \& Wheeler, J. V. (2000). Women corporate directors: Current research and future directions, volume 2. In M. J. Davidson \& D. J. Burke (Eds.), Women in management: Current research issues (pp. 311). London: Paul Chapman Publishers.

8. $\quad$ Bourdieu, P. (1996). The state nobility. Cambridge: Policy Press.

9. Brammer, S., Millington, A., \& Pavelin, S. (2007). Gender and ethnic diversity among UK corporate boards. Corporate Governance: An International Review, 15(2), 393-403.

10. Burke, D. J. (1999). Women on Canadian corporate boards of directors: Getting the numbers right! Corporate Governance: An International Review, 7(4), 374-378.

11. Burke, R. J. (1997). Women directors: Selection, Acceptance and benefits of board membership. Corporate Governance: An International Review, 5(3), 118-125.

12. Campbell, K., \& Mínguez-Vera, A. (2008). Gender diversity in the boardroom and firm financial performance. Journal of Business Ethics, 83(3), 435-451.

13. Carter, D. A., D'Souza, F., Simkins, B. J., \& Simpson, W. G. (2010). The gender and ethnic diversity of US boards and board committees and firm financial performance. Corporate Governance: An International Review, 18(5), 396-414.

14. Carter, D. A., Simkins, B. J., \& Simpson, W. G. (2003). Corporate Governance, board diversity and firm value. Financial Review, 38(1), 33-53.

15. Conyon, M. J., \& Mallin, C. (1997). Women in the boardroom: Evidence from large UK companies. Corporate Governance: An International Review, 5(3), 112-117.

16. D'Aveni, R. A., \& Kesner, I. F. (1993). Top managerial prestige, power and tender offer response: A study of elite social networks and target firm cooperation during takeovers. Organization Science, 4(2), 123-151.

17. Daily, C. M., Certo, S. T., \& Dalton, D. R. (1999). A decade of corporate women: Some progress in the boardroom, none in the executive suite. Strategic Management Journal, 20(1), 93-99. 
18. Dang, R., \& Vo, L.-C. (2012). Women on corporate boards of directors: Facts, figures and analysis. In D. K. Nguyen \& S. Boubaker (Eds.), Board directors and corporate social responsibility (pp. 3-21).

Basingstoke: Palgrave Macmillan.

19. Farrell, K. A., \& Hersch, P. L. (2005). Additions to corporate boards: The effect of gender. Journal of Corporate Finance, 11(1-2), 85-106.

20. Granovetter, M. S. (1978). Threshold models of collective behavior. American Journal of Sociology, 83(6), 1420-1443.

21. Hillman, A. J., Cannella, A. A., \& Harris, I.C. (2002). Women and racial minorities in the boardroom: How do directors differ? Journal of Management, 28(6), 747-763.

22. Jensen, M. C., \& Meckling, W. H. (1976). Theory of the firm: Managerial behavior, agency costs and ownership structure. Journal of Financial Economics, 3(4), 305-360.

23. Johnson, J. L., Daily, C. M., \& Ellstrand, A. E. (1996). Boards of directors: A review and research agenda. Journal of Management, 22(3), 409-438.

24. Kanter, R. M. (1977). Men and women of the corporation. New York: Basic Books.

25. Konrad, A. M., Kramer, V., \& Erkut, S. (2008). The impat of three or more women on corporate boards. Organizational Dynamics, 37(2), 145-164.

26. Morrison, A. M., White, R. P., \& Van Velsor, E., Center for Creative Leadership (1987). Breaking the glass ceiling: Can women reach the top of America's largest corporations? Reading: Addison-Wesley Pub. Co.

27. Moulin, Y., \& Point, S. (2012). Les Femmes dans les Conseils d'Administration du SBF 120 : Qualités Féminines ou Affaires de Famille? Revue de Gestion des Ressources Humaines, 83(1), 31-44.

28. Nekhili, M., \& Gatfaoui, H. (2012). Are demographic attributes and firm characteristics drivers of gender diversity? Investigating women's positions on french boards of directors. Journal of Business Ethics, 112(2), 205-212.

29. Nekhili, M., \& Gatfaoui, H. (2013). Are demographic attributes and firm characteristics drivers of gender diversity? Investigating women's positions on french boards of directors. Journal of Business Ethics, forthcoming.

30. Nguyen, B. D. (2012). Does the rolodex matter? Corporate elite's small world and the effectiveness of boards of directors. Management Science, 58(2), 236-252.

31. Pfeffer, J. (1981). Management as symbolic action: The creation and maintenance of organizational paradigms. In J. Cumming \& B. M. Staw (Eds.), Research in organizational behavior (Vol. 3, pp. 1-52). Greenwich, Conn: JAI Press.

32. Powell, G. N. (1999). Handbook of gender \& work. Thousand Oaks, California: Sage.

33. Sealy, R., Vinnicombe, S., \& Singh, V. (2009). The pipeline of the board finally opens: Women's progress on FTSE 100 boards in the UK. In S. Vinnicombe, V. Singh, D. J. Burke, D. Bilimoria, \& M. Huse (Eds.), Women on corporate boards of directors. Cheltenham: Edward Elgar Publishing Limited.

34. Simpson, W. G., Carter, D. A., \& D'Souza, F. (2010). What do we know about women on corporate boards? Journal of Applied Finance, 2, 27-39.

35. Singh, V., \& Vinnicombe, S. (2004). Why so few women directors in top UK boardrooms? Evidence and theoretical explanations. Corporate Governance: An International Review, 12(4), 479-488.

36. Singh, V., Vinnicombe, S., \& Johnson, P. (2001). Women directors on top UK Boards. Corporate Governance: An International Review, 9(3), 206-216.

37. Tajfel, H., \& Turner, J. C. (1986). An integrative theory of intergroup conflict. In W. G. Austin \& S. Worchel (Eds.), The social psychology of intergroup relations (pp. 7-24). Chicago: Nelson-Hall.

38. Terjesen, S., Sealy, R., \& Singh, V. (2009). Women directors on corporate boards: A review and research agenda. Corporate Governance: An International Review, 17(3), 320-337.

39. Useem, M., \& Karabel, J. (1986). Pathways to top corporate management. American Sociological Review, 51(2), 184-200.

40. van der Walt, N. T., \& Ingley, C. (2003). Board dynamics and the influence of professional background, gender and ethic diversity of directors. Corporate Governance: An International Review, 11(3), 218-234. 